\title{
A new squamate lizard from the Upper Cretaceous Adamantina Formation (Bauru Group), São Paulo State, Brazil
}

\author{
WILLIAM R. NAVA ${ }^{1}$ and AGUSTÍN G. MARTINELLI ${ }^{2}$ \\ ${ }^{1}$ Museu de Paleontologia de Marília, Secretaria Municipal da Cultura e Turismo \\ Prefeitura de Marília, Av. Sampaio Vidal, 245, Centro, 17500-020 Marília, SP, Brasil \\ ${ }^{2}$ Museo de Historia Natural de San Rafael, Parque Mariano Moreno s/n, CP. 5600, San Rafael, Mendoza, Argentina/ \\ Complexo Cultural e Científico Peirópolis/UFTM, BR 262, km 784, Bairro Peirópolis, 38001-970 Uberaba, MG, Brasil \\ Manuscript received on December 10, 2010; accepted for publication on January 24, 2011
}

\begin{abstract}
The record of non-mosasaur squamates (Reptilia, Squamata) is sparse in the Cretaceus fossil record of Brazil and include six putative reports, three from the Aptian-Albian of the Araripe Basin (Tijubina pontei Bonfim-Júnior and Marques, Olindalacerta brasiliensis Evans and Yabumoto, and a lizard indet.) and three from the Upper Cretaceous of the Bauru Group (Pristiguana brasiliensis Estes and Price, Anilioidae gen. et sp. indet., and Squamata gen. et sp. indet.). In this contribution, a new genus and species of lizard, Brasiliguana prudentis gen. et sp. nov., is described based on an isolated left maxilla with teeth. The material was discovered in an outcrop of the Upper Cretaceous Adamantina Formation (Bauru Group) located in the proximity of Presidente Prudente Municipality, São Paulo State, Brazil. The new taxon is considered a basal non-Priscagamidae+Acrodonta iguanian based on the presence of a weakly inclined anterior margin of the maxillary nasal process and maxillary tooth shape and tooth implantation similar to that of iguanians rather than of other lizard groups (e.g. teiids). This finding significantly increases the squamate lizard diversity of South America, which is still poorly understood and sparsely represented in the fossil record.
\end{abstract}

Key words: Bauru Group, Brazil, Iguania, Late Cretaceous, Squamata.

\section{INTRODUCTION}

The record of squamate lizards (the term "lizard" is here informally used to the non-monophyletic non-mosasaur, non-amphisbaenian, non-serpentian squamates) in the Cretaceous of South America is scarce when compared with other regions, such as the United States and Asia (e.g. Alifanov 2004, Borsuk-Bialynicka and Moody 1984, Conrad and Norell 2007, Evans and Wang 2010, Gao and Norell 1998, 2000, Gilmore 1943, Nydam and Cifelli 2002, Nydam et al. 2000).

In South America, Cretaceous lizards have been reported in Argentina and Brazil. A putative record from Chile cited in Gayet et al. (1992) was apparently never

Proceedings of the Third Gondwanan Dinosaur Symposium Correspondence to: Agustín G. Martinelli

E-mail: agustin_martinelli@yahoo.com.ar published (see Albino 2007:105). The findings from Argentina include a partial frontal bone of an indeterminate iguanid from the Cenomanian Candeleros Formation (Río Negro, Argentina; Apesteguía et al. 2005), a dentary fragment of an indeterminate lizard from the Campanian Anacleto Formation (Río Negro, Argentina; Albino 2002, 2007), and probable teiid remains, briefly cited, from the Campanian-Maastrichtian Los Alamitos Formation (Río Negro, Argentina; Albino 2007). In Brazil, the record of Cretaceous lizards is considerably better represented, with findings in Lower and Upper Cretaceous rocks. The Early Cretaceous taxa include the species Tijubina pontei and Olindalacerta brasiliensis from the Aptian-Albian Santana and Crato formations, respectively (Araripe Plateau; Bonfim-Júnior and Marques 1997, Evans and Yabumoto 1998), which were 
considered to represent basal squamatans (e.g. BonfimJúnior and Avilla 2002, Bonfim-Júnior and Rocha-Barbosa 2006, Martill 2007). Also, there is material of an indeterminate lizard from the Crato Formation (Evans and Yabumoto 1998) that has not been studied. The Late Cretaceous records include an articulated sequence of dorsal vertebrae and ribs from the Turonian-Santonian Adamantina Formation at the Municipality of Marília (São Paulo State) interpreted as an indeterminate lizard (Candeiro et al. 2009), and the lizard Pristiguana brasiliensis (Estes and Price 1973) from the CampanianMaastrichtian Marília Formation at Peirópolis town (Municipality of Uberaba, Minas Gerais State). The affinities of Pristiguana are still debated. Originally, it was considered an iguanian (Estes and Price 1973), a hypothesis supported by other authors (Estes 1983, Estes and Báez 1985, Reynoso 1998), but other opinions suggest that Pristiguana possesses affinities with teiids (Borsuk-Bialynicka and Moody 1984). Non-lizard Cretaceous squamates of Brazil are also sparse and represented by a solely anilioid snake from the Adamantina Formation at Ribeirao Buriti (General Salgado Municipality, São Paulo State; Zaher et al. 2003) and Late Cretaceous mosasaur remains from the Pernambuco-Paraíba Basin (records of Globidens, Mosasaurus, and Plioplatecarpinae; Price 1953, 1957, Carvalho and Azevedo 1998), the Sergipe Basin (records of Plioplatecarpus and Platecarpus; Bengtson and Lindgren 2005), the São Luís Basin (Vilas Bôas and Carvalho 2001), and a doubtful record from the Acre Basin (see Bengtson and Lindgren 2005).

In this contribution, an isolated left maxilla with teeth is described and adscript to a new genus and species of lizard, interpreted as having non-Priscagamidae+Acrodonta iguanian affinities (sensu Conrad 2008). The specimen, housed at the Museu Nacional, Rio de Janeiro (Rio de Janeiro State, Brazil), was discovered in 2005 in the proximity of Presidente Prudente Municipality, São Paulo State (Brazil; Fig. 1), from outcrops of the Adamantina Formation (Turonian-Santonian, Upper Cretaceous). Presidente Prudente and surrounding localities (e.g., Álvarez Machado, Pirapozinho, Presidente Bernardes, Santo Anastácio, and Alfredo Marcondes) are widely known for their potentially fossiliferous rocks of Upper Cretaceous age that have produced taxo- nomically diverse material such as invertebrates, turtles, crocodyliforms, and dinosaurs (e.g. Bertini et al. 1993, Dias-Brito et al. 2001, Kellner and Azevedo 1999, Kellner and Campos 1999, 2000, Price 1945). Since 2004, prospecting and excavations carried out at the Presidente Prudente region by the staff of the Museu de Paleontologia de Marília (São Paulo State) recovered several small vertebrate remains that include fishes and anurans remains, titanosaur and abelisaur teeth, diverse types of coprolites, enantiornithe birds (Alvarenga and Nava 2005), and the lizard specimen here described.

The new taxon presented here represents the third lizard record from the Bauru Group (Fernandes and Coimbra 1996) and the sixth from the Cretaceous of Brazil as a whole. The presence of tiny fossil material in the Late Cretaceous outcrops of Brazil can increase our current knowledge about groups rarely represented in the fossil record (Kellner and Campos 1999).

\section{SYSTEMATIC PALEONTOLOGY}

\section{LEPIDOSAURIA Heackel 1866 \\ SQUAMATA Oppel 1811 \\ IGUANOMORPHA Sukhanov 1961 \\ (sensu Conrad 2008) \\ IgUANIA Cuvier 1817 (sensu Conrad 2008) \\ Brasiliguana gen. nov.}

Etymology: Brasil, in reference to its provenance from the Late Cretaceous of Brazil; iguana, from the South American and Caribbean aboriginal language Arawakan iguana,iwana, which refers to the local name for lizard.

Diagnosis: As for the type and only known species.

Type species: Brasiliguana prudentis.

Brasiliguana prudentis sp. nov.

Holotype: MN 7230-V (Coleção de Paleovertebrados, Museu Nacional, Rio de Janeiro, Rio de Janeiro State, Brazil) consists of an isolated left maxilla with partially preserved teeth (Figs. 2 and 3).

Etymology: Prudentis, in reference to Presidente Prudente Municipality, São Paulo State (Brazil), where the holotype was found.

Locality and horizon: The specimen was discovered in the vicinities of Presidente Prudente Municipality, west 

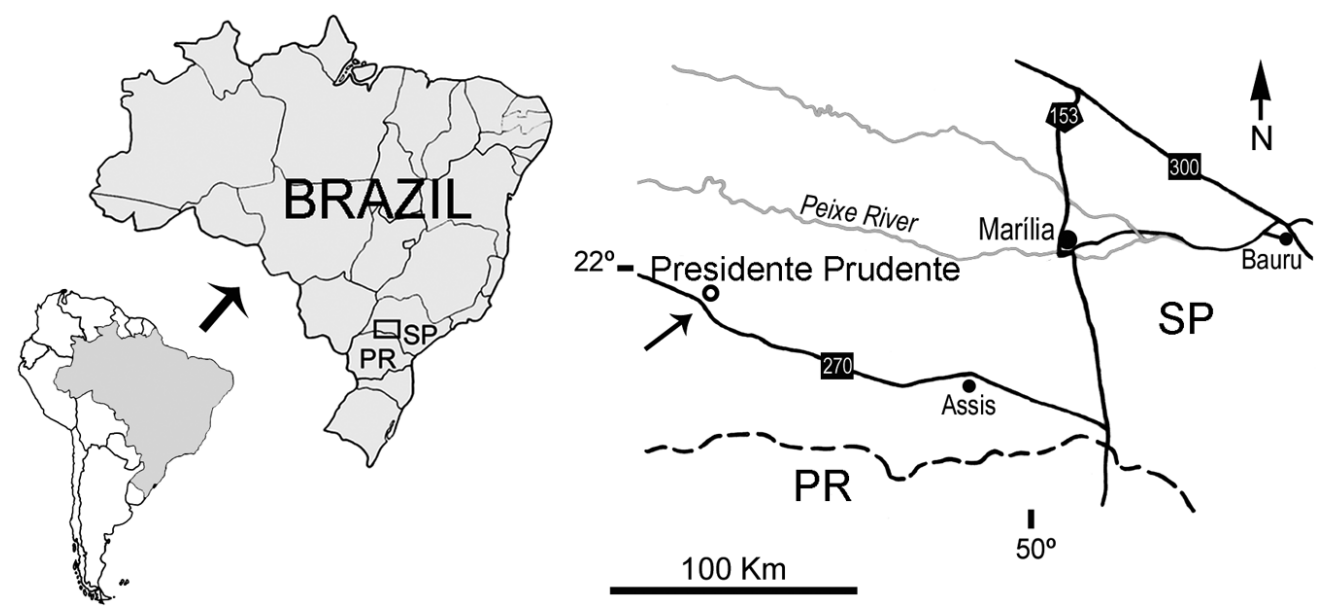

Fig. 1 - Map showing the locality where Brasiliguana prudentis was discovered (arrow), in the vicinities of Presidente Prudente, São Paulo State, Brazil. Abbreviations: PR, Paraná State; SP, São Paulo State.

São Paulo State, southeast Brazil. The outcrop belongs to the Adamantina Formation, Bauru Group; TuronianSantonian, Upper Cretaceous (Fernandes and Coimbra 1996).

Diagnosis: Brasiliguana prudentis differs from other squamatans in the association of the following features: triangular shaped unornamented maxilla with a high nasal process located in the anterior half of bone; weakly inclined anterior margin of the maxillary nasal process; long and thin maxillary jugal process; four conspicuously aligned foramina well above the dental margin; last five teeth placed posterior to the level of the orbital margin; teeth with labial pleurodont implantation; heterodont dentition; mid-maxillary teeth with noticeable constriction of the crown relative to the shaft as occurs in some Tropiduridae and Phrynosomatidae; midmaxillary teeth with main bulbous cusp and very small accessory mesial and distal cusps, smaller than in Tropiduridae and Phrynosomatidae, not flared; and posterior sub-conical teeth with backwardly projecting crown.

\section{DESCRIPTION}

The holotype MN 7230-V of Brasiliguana prudentis consists of an isolated left maxilla with ten partially preserved teeth and space for at least four others. The maxilla is well preserved, with most of its lingual side still embedded in the sandstone matrix. Laterally, the maxilla has a sub-triangular shape, with the dorsal por- tion of the nasal process and the anteriormost portion of the premaxillary process partially broken (Fig. 2). The labial surface of the maxilla is flat to slightly concave, unsculptured, with a shallow anteroposterior step at mid-height that is pierced by four main nutritious foramina. These prominent foramina are located at the level of the second, fifth, eight and tenth teeth positions, respectively (Fig. 2). The anteriormost foramen is the largest and, immediately posterodorsal to it, there is an additional very small foramen. The second and fourth foramina are similarly sized, and the third is the smallest, with a circular shape. The second foramen is circular, laterally opened, and the fourth is drop-shaped, facing posteriorly. Near the dorsal broken edge of the nasal process there are two other foramina, smaller than the others. The dental margin of the maxilla is relatively straight, curving slightly dorsally after the last tooth. In the anterior portion, the maxilla exhibits a rounded, slightly concave edge interpreted as the posterior border of the external nares. The contribution of septomaxilla could not be evaluated. The premaxillary process is anteriorly broken, but based upon the narial and dental edges, it was likely thin, long and horizontal rather than dorsally curved. The base of the nasal process is wide and located in the anterior half of the maxilla. The dorsal border of this process is not totally preserved, but at least it reaches a higher position. The maxilla preserves the postero-dorsal border, but clear contact surfaces for the lacrimal and/or jugal 

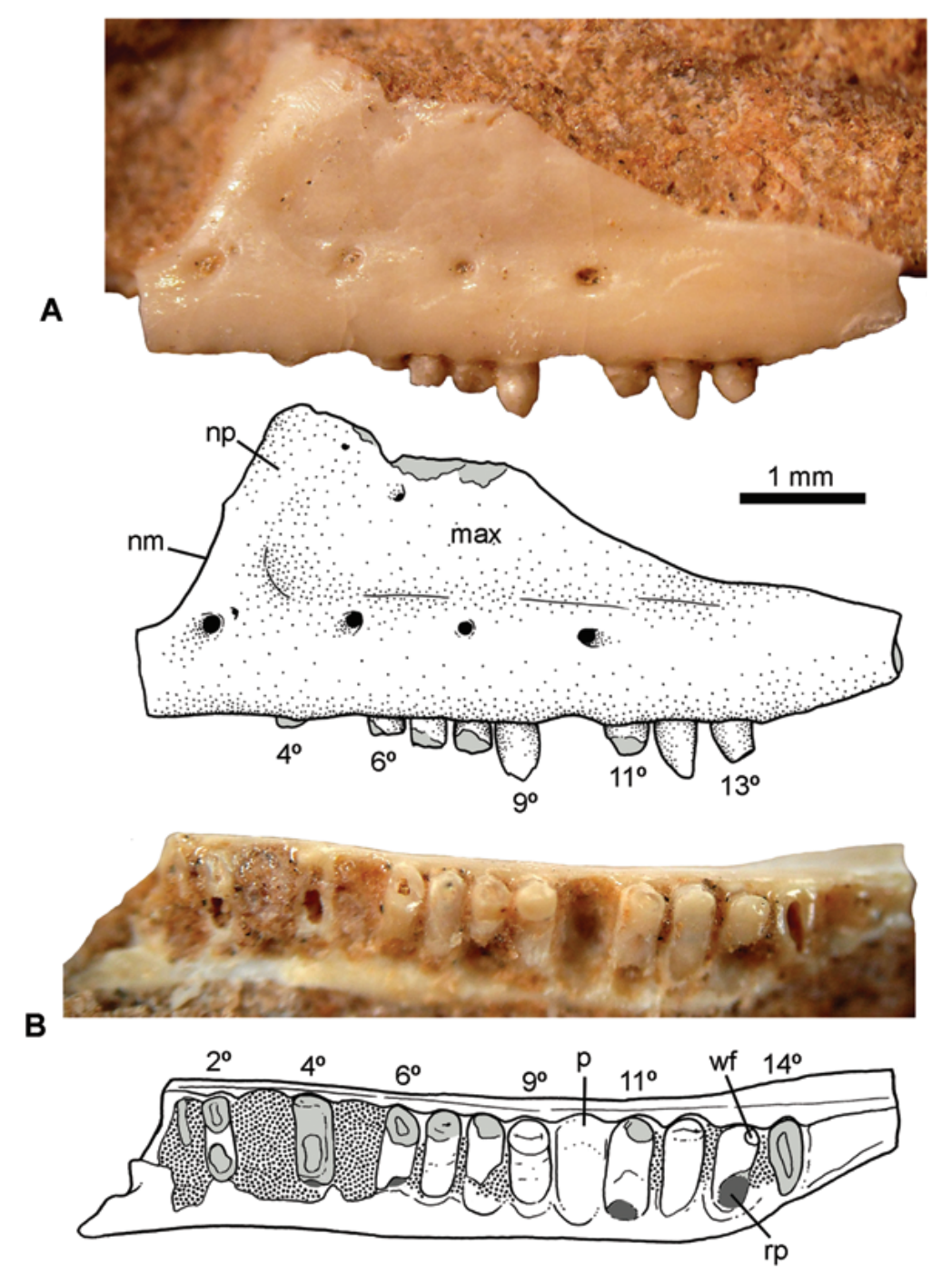

Fig. 2 - Brasiliguana prudentis gen. et sp. nov. Holotype MN 7230-V, left maxilla in lateral (A) and ventral (B) views with accompanying drawings. Light grey indicates broken bone and teeth. Dark grey indicates replacement pits. Regular dotted surfaces indicate main portions with sandstone. Abbreviations: max, maxilla; nm, narial margin; np, nasal process of the maxilla; p, pleura of the maxilla; rp, replacement pit; wf, wear facet. Numbers refer to teeth positions.

bones could not be discerned. This border is slightly concave and sub-parallel to (i.e., posteriorly convergent to) the dental margin (Fig. 2). The jugal process is long and thin, decreasing in height posteriorly from the level of the eighth tooth. Based on these features, at least five teeth are placed posterior to the level of the anterior border of the orbit. In ventral view, the palatine process (or palatine flange) of the maxilla does not possess a medial shelf.

MN 7230-V preserves space for 14 teeth, of which only four have relatively well-preserved crowns. Four- teen teeth possibly correspond to the total upper tooth count for this species. All teeth are synostotically ankylosed to the lingual surface of the pleura of the maxilla, and the teeth are tightly packed without distinctive interdental ridges. This type of tooth implantation, i.e., labial pleurodonty (sensu Zaher and Rieppel 1999), is characteristic of many lizard, groups but absent in varanoids, snakes, acrodonts, and acrodont amphisbaenians (e.g. Zaher and Rieppel 1999). Based on the preserved element, teeth are exposed at approximately $1 / 3$ of the total tooth height. 
The first $\left(1^{\text {st }}\right)$ and second $\left(2^{\text {nd }}\right)$ preserved teeth are broken and were apparently smaller than the following ones, which maintain a similar size along the tooth row. The spaces for the third $\left(3^{\text {rd }}\right)$ and fifth $\left(5^{\text {th }}\right)$ teeth, respectively, are full of sediment. The forth $\left(4^{\text {th }}\right)$ tooth is badly preserved, with only a remnant of the crown and the shaft. At the base of this tooth, there is a depression that possibly corresponds to a replacement pit. The sixth $\left(6^{\text {th }}\right)$ to eighth $\left(8^{\text {th }}\right)$ teeth have their crowns broken at the level of the dental margin. The ninth $\left(9^{\text {th }}\right)$ tooth is the best preserved (Figs. 2 and 3). It is circular in cross section at the level of the dental margin and transversely oval through the shaft. It has a large main cusp with anterior and posterior blunt crests that hold very small mesial and distal accessory cusps. The mesial accessory cusp is placed higher than the distal cusp. The tip of the main cusp is sharp and slightly posteroventrally projected. There is no neck on the shaft. In lateral view, the exposed crown represents about $1 / 3$ of the total tooth height. In lateral view, the mesial and distal outlines are slightly divergent to the base, resulting in a narrower crown. Noticeably, the labial surface of the crown is more convex than the lingual surface. This tooth is apparently a new element due to the lack of wear and the absence of a replacement pit at its base (Fig. 2).

Following the ninth tooth $\left(9^{\text {th }}\right)$, there is an empty cavity (for $10^{\text {th }}$ tooth). The eleventh $\left(11^{\text {th }}\right)$ tooth is intensely worn out apically and labially with an oblique wear surface facing ventrolateraly. In this tooth, there is no clear evidence of accessory cusps. At the base of the eleventh tooth there is a circular pit. The twelfth $\left(12^{\text {th }}\right)$ tooth has a relatively well preserved crown (Figs. 2 and 3). It is sub-conical, with the sharp tip slightly curved posterolingualy, thus differing from the condition observed in the ninth tooth. The crown surface is poorly preserved and the presence of accessory cusps could not be evaluated with confidence. Also, the crown seems to be less globose than in the ninth tooth. The thirteenth $\left(13^{\text {th }}\right)$ tooth is slightly smaller than the preceding one and the tip is strongly worn (Fig. 2). As in the previous tooth, the crown is sub-conical and the portion of preserved crown is posteriorly inclined. At the base of this tooth, there is the largest replacement pit. Finally, the fourteenth $\left(14^{\text {th }}\right)$ tooth is the last element. Only part of the oval root is preserved. The dif- ference in the crown morphology between the ninth and the twelfth-thirteenth teeth (Fig. 3) suggests some degree of heterodonty, as occurs in other lizards (e.g. Brizuela and Albino 2010, Estes et al. 1988, Frost 1992, Montanucci 1968).

\section{COMPARISONS AND DISCUSSIONS}

Brasiliguana prudentis constitutes the second lizard species from the Late Cretaceous of Brazil based on cranial material. The holotype and only known specimen of Pristiguana brasiliensis (Divisão de Geologia e Mineralogia, Rio de Janeiro, DGM-552; Estes and Price 1973) from the Marília Formation at Peirópolis locality (Uberaba, Minas Gerais State) includes a left dentary with teeth, right surangular, fused frontals, left pterygoid, left humerus, and an indeterminate fragment. Unfortunately, the lack of homologous elements hampers detailed comparisons between the two Brazilian fossils. Nonetheless, the teeth of both species exhibit some features that support their distinctiveness. Considering that upper and lower dental morphology have a similar pattern, the tricuspid teeth of Pristiguana exhibit relatively larger accessory cusps and higher crowns and roots than in Brasiliguana (largest tooth of Brasiliguana: $0.9 \mathrm{~mm}$ high; larger tooth of Pristiguana: $1.3 \mathrm{~mm}$ high). The teeth are more tightly packed in Brasiliguana than in Pristiguana, and the posterior conical and curved teeth of Brasiliguana are not present in the lower dentition of Pristiguana (Estes and Price 1973). In Pristiguana, the teeth are columnar with parallel sides, whereas in Brasiliguana (considering the $9^{\text {th }}$ preserved tooth) the crowns are constricted relative to the shafts, giving the appearance of bulbous teeth.
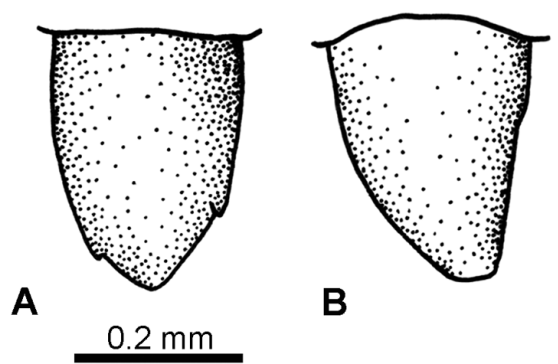

Fig. 3 -Brasiliguana prudentis gen. et sp. nov. Holotype MN $7230-\mathrm{V}$, detail of the crown of the ninth (A) and the twelfth (B) maxillary teeth in labial view. 
The $9^{\text {th }}$ tooth of Brasiliguana exhibits a noticeable constriction of the crown relative to the shaft (Fig. 3), similar to the teeth of the tropidurids Uranoscodon superciliosus, Tropidurus thresiae, Stenocercus guentheri, Microlophus atacamensis, M. quadrivittatus and the phrynosomatid Cophosaurus texanus (see Etheridge and de Queiroz 1988, Frost 1992, Torres-Carvajal 2003, Vidal and Ortiz 2004). This differs from other iguanians that usually possess flared crowns (e.g. Etheridge and de Queiroz 1988, Frost 1992, Montanucci 1968). Despite the morphological similarity of the teeth to the teeth of some Tropiduridae and Phrynosomatidae, the accessory cusps are relatively less prominent in Brasiliguana. Some tropidurids, such as Leiocephalus, have recurved crowns (Frost 1992), as occurs in the posteriormost teeth of Brasiliguana (Fig. 3).

The lack of flared crowns in the tricuspid teeth of Brasiliguana is possibly a primitive feature within iguanians due to the occurrence of flared crowns with better developed cusps in more derived forms (e.g., Etheridge and de Queiroz 1988). This is also concordant with the morphology observed in some phrynosomatids (see above), which are nested as basalmost iguanians (e.g., sensu Conrad 2008).

Despite other lizard groups with tricuspid teeth, such as the teiids Ameiva, Kentropyx, and Cnemidophorus (Presch 1974), the general morphology of the crowns of Brasiliguana is more reminiscent to iguanians than to teiids.

The presence of replacement pits at the base of the $4^{\text {th }}, 6^{\text {th }}, 11^{\text {th }}$, and $13^{\text {th }}$ teeth of Brasiliguana (Fig. 2), rather than interdental placement, suggests tooth replacement typical of iguanians, gekkotans, various scincomorphs, and some anguids (Edmund 1969, Estes et al. 1988, Rieppel 1978).

Unfortunately, none of the synapomorphies of the clade Iguania listed by Estes et al. (1988) and by Conrad (2008) could be evaluated in Brasiliguana due to the fragmentary nature of the holotype. Nonetheless, Brasiliguana possesses a synapomorphy of the Iguania clade (exclusive of phrynosomatids) sensu Conrad (2008): the presence of a weakly inclined anterior margin of the maxillary nasal process (Fig. 2). Among the Squamata, this same character-state was found in some Priscagamidae (e.g. Priscagama gobiensis; Gao and Norell
2000), in Serpentes, and in Varanoidea (e.g. Conrad 2008). Differing from Brasiliguana, the priscagamid lizards have acrodont dentition and exhibit dermal sculpturing on the maxilla (Conrad 2008, Gao and Norell 2000). Consequently, the presence of this characterstate in Brasiliguana plus the type of tooth implantation indicates strong evidence for its inclusion within the Iguania as a non-Priscagamidae + Acrodonta taxon (sensu Conrad 2008). In other words, following the phylogenetic hypothesis of Estes et al. (1988; see also, for example, Smith 2009), Brasiliguana could be considered as a member of the Iguania clade positioned closer to the traditional "Iguanidae" (a paraphyletic assemblage of non-acrodont lizard groups; also called Pleurodonta, see Frost et al. 2001, Evans and Jones 2010) than to acrondont lizards.

The shape of the premaxillary and nasal processes, the row of labial nutritious foramina and their placement with regard to the dental margin, and the shape of the orbital contribution of the maxilla is similar to the condition of other fossil iguanians such as the Late Cretaceous Mongolian Saichangurvel davidsoni (Conrad and Norell 2007), Temujinia ellisoni (Gao and Norell 2000), Ctenomastax parva (Gao and Norell 2000), the Miocene Armandisaurus exploratory (New Mexico, USA; Norell and de Queiroz 1991), and the current Tropidurus and Tapinurus (Frost 1992). Despite the similar morphology of the maxillary, the teeth of Brasiliguana differ from these taxa in the lack of flaring and complex crowns (see above). The unornamented surface of the maxilla of Brasiliguana is also similar to the condition of most iguanians and different from the condition of others lizards such as cordyloideans and teiids (e.g. Conrad 2008), in which the maxillae are ornamented.

Due to the fragmentary nature of the only known material of Brasiliguana, the phylogenetic placement of the Brazilian fossil within lizards is only partially resolved. The above mentioned resemblances of the maxilla and dentition with members of the basal clade Iguania (e.g. Estes et al. 1998, Conrad 2008) may suggest that Brasiliguana is likely a plesiomorphic nonPriscagamidae+Acrodonta iguanian. Iguanians of Late Cretaceous age (e.g. Conrad and Norell 2007, Gao and Norell 2000) exhibit complex dental elements with multicuspidate and flared crowns, considerably differ- 
ent from the condition of Brasiliguana, possibly supporting its basal position. Moreover, the morphology of the teeth of Brasiliguania is similar to that present in members of the basal family phrynosomatid and in some tropidurids.

New materials from rich fossiliferous localities of Late Cretaceous age in southeast Brazil will be necessary for more precise taxonomic discussions and for a better understanding of the origin and diversity of Mesozoic squamatan lizards in South America and their bearing in Squamate phylogeny.

\section{ACKNOWLEDGMENTS}

We especially thank H.M.F. Alvarenga (Museu de História Natural de Taubaté, SP) for the preparation of the material and J.J.W. Sertich (Department of Anatomical Sciences, Stony Brook University, New York) for suggestions and English corrections. Two anonymous reviewers and the Editor A.W.A Kellner made several suggestions that greatly improved the Ms. A.G.M. is supported by a Conselho Nacional de Desenvolvimento Científico e Tecnológico (CNPq/Brazil) scholarships under the direction of V.P.A. Teixeira (CCCP/UFTM).

\section{RESUMO}

Os achados de escamados (Reptilia, Squamata) são escassos no Cretáceo do Brasil, incluindo cinco registros pontuais, dois do Aptiano-Albiano da Bacia do Araripe (Tijubina pontei Bonfim-Júnior e Marques e Olindalacerta brasiliensis Evans e Yabumoto), e três do Cretáceo Superior do Grupo Bauru (Pristiguana brasiliensis Estes and Price, Anilioidae gen. et sp. indet., Squamata gen. et sp. indet.). Nesta contribuição apresentamos um novo gênero e espécie de lagarto, Brasiliguana prudentis, baseado numa maxila esquerda com dentição. O material provém de depósitos da Formação Adamantina aflorantes próximos a cidade de Presidente Prudente, Estado de São Paulo, Brasil. O novo táxon é considerado um iguanídeo não-Priscagamidae+Acrodonta baseado na presença de uma margem anterior do processo nasal do maxilar pouco inclinada e na morfologia maxilar e dentaria mais semelhante à de outros iguanideos que a outros grupos de lagartos (ex. teiídeos). A presente descoberta aumenta a diversidade de lagartos escamados na América do Sul onde o registro fóssil é ainda raro.

Palavras-chave: Grupo Bauru, Brasil, Iguania, Cretáceo Superior, Squamata.

\section{REFERENCES}

Albino AM. 2002. El lagarto más antiguo de la Argentina. $I^{\circ}$ Congreso ‘Osvaldo A. Reig' de Vertebradología Básica y Evolutiva e Historia y Filosofía de la Ciencia, Resúmenes, Buenos Aires, $21 \mathrm{p}$.

Albino AM. 2007. Lepidosauromorpha. In: GASPARINI Z, Coria RA AND SAlgado L (Eds), Patagonian Mesozoic Reptiles, Bloomington: Indiana University Press, USA, p. 87-115.

Alifanov VR. 2004. Parauromastyx gilmorei gen. et sp. nov. (Isodontosauridae, Iguania), a new lizard from the Upper Creraceous of Mongolia. Paleontological Journal 38: 206-210.

Alvarenga H AND NAVA WR. 2005. Aves Enantiornithes do Cretáceo Superior da Formação Adamantina do Estado de São Paulo, Brasil. II $^{\circ}$ Congresso Latino-Americano de Paleontologia de Vertebrados, Boletim de Resumos, Rio de Janeiro, 20 p.

Apesteguía S, Agnolin FL and Lío G. 2005. An early Late Cretaceous lizard from Patagonia, Argentina. CR Palevol 4: 311-315.

Bengtson P And Lindgren J. 2005. First record of the mosasaur Platecarpus Cope, 1869 from South America and its systematic implications. Rev Bras Paleont 8: 512.

Bertini RJ, Marshall LG, Gayet M and Brito P. 1993. Vertebrate faunas from the Adamantina and Marília Formations (Upper Bauru Group, Late Cretaceous, Brazil). N Jb Geol Paläont Abh 188: 71-101.

BRIZUEla S AND Albino AM. 2010. Variaciones dentarias en Tupinambis merianae (Squamata: Teiidae). Cuad herpetol 24: 5-16.

BONFIM-JÚNIOR FC AND AVILlA L. 2002. Phylogenetic position of Tijubina pontei Bonfim-Júnior and Marques, 1997 (Lepidosauria, Squamata), a basal lizard from the Santana Formation, Lower Cretaceous of Brazil. J Vert Paleont 22(A): 37-38.

BonfIM-JÚNIOR FC AND MARQUES RB. 1997. Um novo lagarto do Cretáceo do Brasil (Lepidosauria, Squamata Formação Santana, Aptiano da Bacia do Araripe). Anu Inst Geocienc 20: 215-232.

BonfIM-JÚnIOR FC AND RochA-BARbosa O. 2006. A Paleoautoecologia de Tijubina pontei Bonfim-Júnior and Marques, 1997 (Lepidosauria, Squamata Basal da Formação Santana, Aptiano da Bacia do Araripe, Cretáceo Inferior do Nordeste do Brasil). Anu Inst Geocienc 29: $54-65$. 
Borsuk-Bialynicka M And Moody SM. 1984. Priscagaminae, a new subfamily of the Agamidae (Sauria) from the Late Cretaceous of the Gobi Desert. Acta Palaeont Pol 29: 51-81.

CANDEIro CR, Nava W, Martinelli AG, Forasiepi AM, Scanferla CA And Muzzopappa P. 2009. New lizard record (Diapsida; Lepidosauria) from the Late Cretaceous Adamantina Formation, Brazil. Bull Geosci 84: 573-576.

Carvalho LB and Azevedo SAK. 1998. Proposta taxonômica para os répteis marinhos (Lepidosauria, Mosasauridae) do Neocretáceo da Bacia Pernambuco-Paraíba, Nordeste do Brasil. Bol Mus Nac, Geol 43: 1-14.

CONRAD JL. 2008. Phylogeny and systematic of Squamata (Reptilia) based on morphology. Bull Am Mus Nat Hist 310: 1-182.

Conrad JL and Norell MA. 2007. A complete Late Cretaceous iguanian (Squamata, Reptilia) from the Gobi and identification of a new iguanian clade. Am Mus Nov 3584: $1-47$.

Dias-Brito D, Musacchio EA, Castro JC, MaraNHÃo MSA, SUÁREZ JM AND Rodrigues R. 2001. Grupo Bauru: uma unidade continental do Cretáceo do Brasil - concepções baseadas em dados micropaleontológicos, isotópicos e estratigráficos. Rev Paleobiol 20: 245-304.

Edmund G. 1969. Dentition. In: Gans C, Bellairs A AND PARSONS $T$ (Eds), Biology of the Reptiles I (Morph. A), New York: Academic Press, USA, p. 117200.

ESTES R. 1983. Sauria terrestria, Amphisbaenia. In: WeLLNHOFER P (Ed), Handbuch der Paläoherpetologie, Stuttgart: Gustav Fischer Verlag, Germany, 249 p.

Estes R AND BÁEZ AM. 1985. Herpetofaunas of North and South America during the Late Cretaceous and Cenozoic: evidence for interchange? In: STEHLI FG AND WeBB SD (Eds), The Great American Biotic Interchange, Plenum Press, New York, p. 139-195.

Estes R, De Queiroz K And Gauthier J. 1988. Phylogenetic relationships within Squamata. In: ESTES R AND Pregill G (Eds), Phylogenetic Relationships of the Lizard Families. Essays commemorating Charles L. Camp, California: Stanford University Press, USA, p. 119-281.

Estes R AND PRICE LI. 1973. Iguanid lizard from the Upper Cretaceous of Brazil. Science 180: 748-751.

ETHERIDGE R AND DE QUeIRoz K. 1988. A phylogeny of Iguanidae. In: Estes R AND Pregill G (Eds), Phylogenetic Relationships of the Lizard Families. Essays com- memorating Charles L. Camp., Stanford, California: Stanford University Press, USA, p. 283-367.

Evans SE AND JONES MEH. 2010. The origin, early history and diversification of lepidosauromorph reptiles. In: BANDYOPADHYAY B (Ed), New Aspects of Mesozoic Biodiversity, Berlin: Springer-Verlag Berlin Heidelberg, Germany, p. 27-44.

Evans SE AND WANG Y. 2010. A new lizard (Reptilia: Squamata) with exquisite preservation of soft tissue from the Lower Cretaceous of Inner Mongolia, China. J Syst Palaeont 8: 81-95.

Evans SE AND YABUmoto Y. 1998. A lizard from the Early Cretaceous Crato Formation, Araripe Basin, Brazil. N Jb Geol Paläont Mh 6: 349-364.

Fernandes LA And Coimbra AM. 1996. A Bacia Bauru (Cretáceo Superior, Brasil). An Acad Bras Cienc 68: 195-105.

Frost DR. 1992. Phylogenetic analysis and taxonomy of the Tropidurus group of lizards (Iguanidae: Tropiduridae). Am Mus Nov 3033: 1-68.

Frost DR, Etheridge R, JANiEs D AND TItUs TA. 2001. Total evidence, sequence alignment, evolution of polychrotid lizards, and a reclassification of the Iguania (Squamata: Iguania). Am Mus Nov 3343: 1-38.

GAO K AND NOREll MA. 1998. Taxonomic revision of Carusia intermedia (Reptilia: Squamata) from the Upper Cretaceous of Gobi Desert and phylogenetic relationships of anguimorphan lizards. Am Mus Nov 3230: 1-51.

GaO K AND Norell MA. 2000. Taxonomic composition and systematics of Late Cretaceous lizard assemblages from Ukhaa Tolgod and adjacent localities, Mongolian Gobi desert. Bull Am Mus Nat Hist 249: 1-118.

Gayet M, Rage JC, SAmpere T And Gagnier PY. 1992. Modalité des exchanges de vertebrés continentaux entre l'Amérique du Nord et l'Amerique du Sud au Cretacé superior et au Paléocéne. Bull Soc Geol France 163: 781791.

GiLmORE CW. 1943. Osteology of Upper Cretaceous lizards from Utah, with a description of a new species. Proc Unit Stat Nat Mus 93: 209-214.

Kellner AWA And Azevedo SAK. 1999. A new sauropod dinosaur (Titanosauria) from the Late Cretaceous of Brazil. Nat Sci Mus Monogr 15: 111-142.

Kellner AWA And CAmpos DA. 1999. Vertebrate Paleontology in Brazil - a review. Episodes 22(3): 238-251.

Kellner AWA AND CAmpos DA. 2000. Brief review of dinosaur studies and perspectives in Brazil. An Acad Bras Cienc 72: 509-538. 
Martill DM. 2007. Lizards of the Crato Formation. In: MARTILl DM, Bechly G AND Loveridge RF (Eds), The Crato fossil beds of Brazil. Window into an ancient world, Cambridge: Cambridge University Press, England, p. $458-462$.

MontAnUCCI RR. 1968. Comparative dentition in four iguanid lizards. Herpetologica 24: 305-315.

Norell MA AND DE QUEIROZ K. 1991. The earliest iguanine lizard (Reptilia: Squamata) and its bearing on Iguanine phylogeny. Am Mus Nov 2997: 1-16.

NydAM RL AND CIFELli RL. 2002. A new teiid lizard from the Cedar Mountain Formation (Albian-Cenomanian boundary) of Utah. J Vert Paleont 22: 276-285.

Nydam RL, Gauthier JA And Chiment JJ. 2000. The mammal-like teeth of the Late Cretaceous lizard Peneteius aquilonius Estes 1969 (Squamata, Teiidae). J Vert Paleont 20: 628-631.

PRESCH W. 1974. A survey of the dentition of the macroteiid lizards (Teiidae: Lacertilia). Herpetologica 30: 344-349.

PRICE LI. 1945. A new reptile from the Cretaceous of Brazil. Div Geol Min, Notas Prel e Est 25: 1-9.

PRICE LI. 1953. Restos de mosassáurios de Pernambuco, e considerações sôbre a presença dêstes répteis na Bacia Amazônica do Brasil. Div Geol Min, Notas Prel e Est 58: $1-15$.

PRICE LI. 1957. A presença de Globidens no Cretáceo Superior do Brasil. Bol Dep Nac Prod Min, DGM 169: 1-24.

REYNoso VH. 1998. Huehuecuetzpalli mixtecus gen. et sp. nov. A basal squamate (Reptilia) from the Early Cretaceous of Tepexi de Rodríguez, central Mexico. Phil Trans R Soc B 353: 477-500.
RIEPPEL O. 1978. Tooth replacement in anguinomorph lizards. Zoomorphologie 91: 77-90.

SMITH KT. 2009. Eocene lizards of the Clade Geiseltaliellus from Messel and Geiseltal, Germany, and the early radiation of Iguanidae (Reptilia: Squamata). Bull Peabody Mus Nat Hist 50: 219-306.

Torres-CARVAJAL O. 2003. Cranial osteology of the Andean lizard Stenocercus guentheri (Squamata: Tropiduridae) and its postembryonic development. J Morph 255: 94-113.

VidAl MA AND ORTIZ JC. 2004. Análisis osteológico en dos especies de Microlophus (Sauria, Tropiduridae) de la costa Chileno-Peruana. Gayana 68: 9-19.

VILAS BÔAS I AND CARVALHO IS. 2001. Répteis marinhos (Mosasauria e Plesiosauria) do Cretáceo Superior da Bacia de São Luís (Maranhão, Brasil). In: Rossetti DF, Góes AM AND TRuckenbrodt W (Eds), O Cretáceo na Bacia de São Luís-Grajaú, Belém: Museu Paraense Emílio Goeldi, p. 223-233.

Zaher HD, LANGer MC, FAra E, CARVAlho IS AND ARRUDA JT. 2003. A mais antiga serpente (Anilioidea) brasileira: Cretáceo Superior do Grupo Bauru, General Salgado, SP. Paleontologia em Destaque 44: 50-51.

ZAHER HD AND RIEPPEL O. 1999. Tooth implantation and replacement in squamates, with special reference to mosasaur lizards and snakes. Am Mus Nov 3271: 1-19. 